\title{
Postprandial molecular responses in the liver of the barramundi, Lates calcarifer.
}

Nicholas M. Wade ${ }^{1 *}$, Sandrine Skiba-Cassy², Karine Dias ${ }^{2}$, and Brett D Glencross ${ }^{1}$.

1. CSIRO Food Futures Flagship, Division of Marine and Atmospheric Research, Ecosciences Precinct, Dutton Park, QLD 4102, Australia.

2. INRA, UMR 1067 Nutrition Aquaculture and Génomique, Pôle d'hydrobiologie, CD 918, F64310 Saint Pée-sur-Nivelle, France

* Author for correspondence (email: nick.wade@csiro.au)

Abstract

The regulation of gene expression by nutrients is an important mechanism governing energy storage and growth in most animals, including fish. Understanding the timing and intensity of these responses is the first critical step in defining the molecular effects of different dietary nutrient sources. In this study, changes in key metabolic regulators of nutritional pathways were investigated in barramundi fed a meal of a diet formulated with 500, 150 and $110 \mathrm{~g} \mathrm{~kg}^{-1}$ dry matter of protein, lipid and carbohydrate, respectively. Plasma glucose levels showed a postprandial peak two hours after feeding, and had returned to basal levels within four hours. Significant activation of genes that regulate glycolytic and lipogenic pathways immediately post feeding were observed, in combination with down-regulation of genes that control gluconeogenesis and activation of the Akt-mTOR pathway. Strong correlations were identified between a number of different metabolic genes, and the coordinated co-regulation of these genes may underlie the ability of this fish to effectively regulate circulating plasma glucose levels. Overall, post-prandial responses in barramundi were observed to be extremely rapid compared with other fish species, and there was no prolonged hyperglycaemia with a diet low in carbohydrates. These data clearly demonstrate, for the first time, the molecular changes that control intermediary metabolism in barramundi in response to feeding a single meal of a diet formulated within optimal specifications for this species. 
Keywords

Fish, Liver, Metabolism, Nutrigenomics 
Introduction

The basic goal of fish nutrition in aquaculture is to supply adequate amounts of energy to promote optimal growth. Understanding the molecular pathways that regulate the utilization of dietary energy and macronutrients is a critical element to understanding the feeding and growth response in fish. In order to use molecular responses to understand fish nutrition, the first step is to define the molecular responses that occur each time a fish receives food. The changes in gene expression after feeding have been investigated for various metabolic genes in a range of fish species, although there is considerable variation in the molecular responses of different fish to nutrients, particularly in response to carbohydrates (reviewed in Panserat and Kaushik 2010; Polakof et al. 2012). In barramundi, there is no understanding of the changes in expression of any genes that regulate key energy partitioning pathways or the induction of signalling cascades after feeding.

Barramundi, like salmon and trout, are an economically important, carnivorous fish species. Traditionally, aquaculture production of these species has relied on diets containing high levels of protein and lipid, based on wild-harvest fishmeal and fish oil. The need to reduce the reliance on wild fisheries resources has resulted in the increased use of plant based raw materials such as soybean meal, lupid meals (Gatlin et al. 2007; Glencross et al. 2007). However, this introduces a range of complex carbohydrates, such as cellulose, polysaccharides and starches (Gatlin et al., 2007; Glencross et al. 2007). Whilst these complex carbohydrates do not form part of the natural diet for carnivorous fish, most fish species have the capacity to digest various types of grains, particularly after extrusion and gelatinisation (Bergot and Breque 1983; Glencross et al. 2011a, 2011b; Jeong et al. 1991; Wilson 1994). This is also the case for barramundi (Allan et al. 2003; Catacutan and Coloso 1997; Glencross et al. 2011c, 2012).

Past studies have shown that barramundi growth performance and feed conversion ratio (FCR) is maximised when feeds contain 450-550 $\mathrm{g} \mathrm{kg}^{-1}$ dry matter (DM) of protein, 140-160 $\mathrm{g} \mathrm{kg}^{-1} \mathrm{DM}$ of lipid and between 18-22 $\mathrm{MJ} \mathrm{kg}^{-1}$ 
gross energy (reviewed in Glencross et al. 2006). Barramundi, like most fish, have no specific nutritional requirement for carbohydrates, and have been shown to be intolerant of high levels of simple carbohydrates compared with omnivorous and herbivorous fish (Allan et al. 2003). In addition, the digestibility of the carbohydrate component of different plant based raw ingredients has been shown to be extremely variable (Allan et al. 2003; Glencross et al. 2012). As a consequence, levels of carbohydrates in commercial diets for barramundi are generally limited to under $20 \%$, with formulations focussing on achieving high protein content. Carbohydrate is included primarily as a binding agent and secondarily as a minor source of energy, and at levels of $10-20 \%$ there has been shown to be little effect on the growth performance or protein digestibility (Allan et al. 2003; Glencross et al. 2012).

In this study, a diet was formulated within optimal protein and lipid specifications for this species, while carbohydrate levels were kept to minimum levels required for pellet binding and extrusion. Changes in barramundi plasma glucose and free amino acid levels were investigated over time after feeding. In addition, the molecular responses of key genetic regulators of energy partitioning pathways in the liver, including carbohydrate, fatty acid, amino acid and glycogen metabolism were examined, and the activation of signalling cascades that regulate growth and metabolism assessed. This study seeks to define the post-prandial changes in liver gene expression that regulate a range of metabolic pathways in barramundi, and assess the timing of signalling cascade activation that regulate downstream growth pathways over time after a fish receives food. 


\section{Methods}

Fish and Experimental Protocol

All experiments were performed in accordance with the Australian code of practice for the care and use of animals for scientific purposes and were approval by the CSIRO Animal Ethics Committee (approval number: A8/2010). Barramundi (Lates calcarifer) were held indoors under artificial lighting in $200 \mathrm{~L}$ tanks receiving $\sim 2 \mathrm{Lmin}^{-1}$ flow of continuously aerated marine water at $30^{\circ} \mathrm{C}$ and salinity at $35 \mathrm{gL}^{-1}$. Two tanks, each containing 24 fish $(99.3 \pm 7.8 \mathrm{~g}$ and 99.4 $\pm 11.8 \mathrm{~g}$, respectively), were fed to apparent satiety twice daily (0830 and 1600) using the diet outlined in Table 1. This diet was designed using optimal protein, lipid and energy requirements for barramundi of this size (Glencross et al. 2006). Nutritional composition and digestibility of individual ingredients had been calculated from other studies (Glencross et al. 2012).

Fish were fed for five days, then once on Day six (0830) and starved for $24 \mathrm{hr}$ to ensure that no effects were present from previous feeding events. On Day seven, fish weighed $113.2 \pm 11.8 \mathrm{~g}$ and $109.7 \pm 16.5 \mathrm{~g}$, respectively. Three fish were sampled from each of the two tanks as a pre-feeding control one hour before a $100 \mathrm{~g}$ ration of the experimentally prepared diet was fed to each of the two tanks over a 10 min feeding event. Three fish were then sampled from each of the two tanks at $30 \mathrm{~min}, 1 \mathrm{hr}, 2 \mathrm{hr}, 4 \mathrm{hr}, 8 \mathrm{hr}, 12 \mathrm{hr}$ and $24 \mathrm{hr}$ post feeding. For sampling, fish were euthanized by placing them in seawater containing $0.2 \mathrm{ml} \mathrm{L}^{-1}$ AQUI-S (AQUI-S New Zealand Ltd). Stomach contents recorded over the first four hours showed that sampled fish ate an average of $3.1 \pm 1.31 \mathrm{~g}$ of feed. Blood was collected by caudal vein puncture using a syringe pre-treated with a solution containing $0.2 \mathrm{M}$ EDTA, then centrifuged and plasma kept frozen at $-80^{\circ} \mathrm{C}$ until analysis. Liver samples were collected, snap frozen on dry ice then stored at $80^{\circ} \mathrm{C}$ prior to further RNA and protein analyses.

Metabolite assays

Plasma and liver glucose levels $(n=6)$ were measured using a commercially available glucose assay kit (BioVision \#K606-100). Plasma free amino acids (FAA) were determined using a fluorometric detection method (Fisher et al. 2000) and using Amino Acid Standard H (Pierce \#20088) as a reference.

Quantitative real-time RT-PCR. 
Total RNA was extracted using Trizol reagent (Invitrogen) according to the manufacturers instructions, and precipitated by adding 0.5 volumes of isopropyl alcohol and 0.5 volumes of RNA precipitation solution (1.2 M sodium chloride, $0.8 \mathrm{M}$ disodium citrate) for purity improvement (Green and Sambrook 2012). Total RNA was DNase digested with the Turbo DNA-free kit (Applied Biosystems). RNA quantity was assessed on a NanoDrop spectrophotometer (NanoDrop Technologies) and RNA quality was assessed using a Bioanalyser (Agilent Technologies) and RNA nanochips (Agilent \#5067-1511). All RNA samples were diluted to $200 \mathrm{ng} \mu \mathrm{l}^{-1}$. Reverse transcription was performed on $1 \mu \mathrm{g}$ of total RNA using Superscript III (Invitrogen) with $25 \mu \mathrm{M}$ oligo(dT) 20 and $25 \mu \mathrm{M}$ random hexamers (Resuehr and Spiess, 2003). Expression of a range of genes that regulate various metabolic pathways in all samples was analyzed by realtime PCR as described below.

Real-time PCR primers specific to each gene of interest (Table 2) were designed with PerlPrimer v1.1.17 (Marshall, 2004). Verification that there was no genomic DNA contamination was carried out by PCR amplification of a pool of DNAsetreated RNA samples using gene-specific primers. In all cases, PCR efficiency (E) was optimized to be between $95 \%$ and $105 \%$ using the slope of a standard curve over a five-fold serial dilution of a pooled cDNA sample containing all samples. Real-time PCR amplification reactions were carried out using 1 X SYBR Green PCR Master Mix (Applied Biosystems), $0.2 \mu \mathrm{mol}^{-1}$ of each primer and the equivalent of 7.5 ng of reverse-transcribed RNA. Amplification cycle conditions were $2 \mathrm{~min}$ at $50^{\circ} \mathrm{C}, 10 \mathrm{~min}$ at $95^{\circ} \mathrm{C}$ followed by 40 cycles of $15 \mathrm{sec}$ at $95^{\circ} \mathrm{C}$ and $40 \mathrm{sec}$ at $60^{\circ} \mathrm{C}$. Amplification specificity was verified by cloning and sequencing and a dissociation melt curve analysis was routinely performed to assess amplified transcripts. Reactions were set up using the epMotion 5070 robot (Eppendorf) and run in triplicate on a Viia7 real-time PCR system (Applied Biosystems). Normalization was performed using the $\Delta C \mathrm{q}$ method (where $C \mathrm{q}$ is the quantification cycle), as it was considered the least biased approach (de Santis et al., 2011). Expression levels of each gene relative to one another were determined by normalizing the cycle threshold values for each gene to Ef1 $\alpha$, then to the average cycle threshold of all genes at each time point to express relative transcript abundance. Changes in expression levels of each gene over time were 
determined by normalizing the cycle threshold values for each gene to Ef1 $\alpha$, then to the cycle threshold of each gene at time zero. The variation in amplification of Ef1 $\alpha$ across all samples was 0.68 cycles and did not significantly change over time (data not presented). The gene Ef1 $\alpha$ has been routinely used as a reference gene for gene expression analysis in barramundi (de Santis et al. 2011) and for postprandial metabolic gene expression analysis other species (Craig and Moon 2011; Enes et al. 2012; Menningen et al. 2012; Olsvik et al. 2004; Skiba-Cassy et al. 2009).

\section{Protein Extraction and Western Blotting}

Frozen liver samples ( 100 mg) were homogenized on ice with an Ultraturrax homogenizer in a buffer containing $150 \mathrm{mmol} \mathrm{l}^{-1} \mathrm{NaCl}, 10 \mathrm{mmol} \mathrm{l}^{-1}$ Tris, $1 \mathrm{mmol} \mathrm{l}^{-1}$ EGTA, $1 \mathrm{mmol} \mathrm{l}^{-1}$ EDTA (pH 7.4), $100 \mathrm{mmoll}^{-1}$ sodium fluoride, $4 \mathrm{mmol} \mathrm{l}^{-1}$ sodium pyrophosphate, $2 \mathrm{mmol} \mathrm{l}^{-1}$ sodium orthovanadate, $1 \%(\mathrm{v} / \mathrm{v})$ Triton $\mathrm{X}-100,0.5 \%$ (v/v) NP40-IGEPAL and a protease inhibitor cocktail (Roche). Homogenates were centrifuged at $1000 \mathrm{xg}$ for $15 \mathrm{~min}$ at $4^{\circ} \mathrm{C}$ and supernatants were then centrifuged for $30 \mathrm{~min}$ at $15000 \mathrm{x}$ g. The resulting supernatants $(\mathrm{n}=6$ for each time point) were stored at $-80^{\circ} \mathrm{C}$. Protein concentrations were determined using the Bio-Rad Protein assay kit. Quantities of $20 \mu \mathrm{g}$ protein per sample were separated by SDS-PAGE and analysed for the presence of specific proteins by western blotting and using the appropriate antibodies. Primary antibodies for the analysis of the insulin signaling pathway were obtained from Cell Signaling Technologies (Akt-p \#9272; Akt \#9271; mTOR-p \#2972; mTOR\#2971S; S6-p \#4856S; S6 \#2217S). All were used at a dilution of 1:1000 and have previously been shown to cross-react with rainbow trout proteins of interest (Seiliez et al. 2008). After incubation with a goat anti-rabbit IRDye infrared secondary antibody (LI-COR Inc. Biotechnology), bands were visualized and quantified by Infrared fluorescence using the OdysseyH Imaging System (LI-COR Inc. Biotechnology).

\section{Statistical Analyses}

Where comparison between individual measurements was required, statistical significance was assessed by single factor analysis of variance (ANOVA), followed by Tukey's HSD test allowing 5\% error. A Pearson correlation was used to determine linear dependence between measurements, using a $5 \%$ confidence 
interval and a Student's t-test to attribute statistical significance. All statistical analyses were performed using StatPlus:Mac 2009 (AnalystSoft Inc, 2009). 
Results

\section{Metabolites}

Plasma glucose levels peaked two hours post-feeding, and then returned to initial levels by 4 hours (Table 3). The levels at 2 hours after a meal were significantly different from those recorded at 8, 12 and 24 hours after a meal. Liver glucose levels remained stable throughout the various time points (Table 3). Plasma free amino acids were significantly elevated 2 and 4 hours after feeding, and had returned to pre-feeding levels by 8 hours (Table 3).

Relative Differences in Liver Transcript Levels During Starvation

Transcript levels of each gene were calculated relative to one another using raw cycle threshold values for each gene, normalised to Ef1 $\alpha$, relative to the average Ct value for all the genes at either before feeding or 2 hours after feeding. Among the 18 genes analysed in this study, the gluconeogenic gene glucose-6phosphatase (EC 3.1.3.9; Lc G6Pase) showed the highest expression in the liver of barramundi that had been starved for 24 hours (Figure 1). The next most abundant transcripts were fructose-1,6-bisphosphatase (EC 3.1.3.11; Lc F1,6BPase) and glutamate dehydrogenase (EC 1.4.1.2; Lc GLUD1) which had very similar total expression levels.

Transcript levels of genes that regulate the glycolysis (glucokinase: EC 2.7.1.1; Lc $G K$, and pyruvate kinase: EC 2.7.1.40; $L c P K)$ ), pentose phosphate pathway (glucose-6-phosphate dehydrogenase: EC 1.1.1.49; Lc G6PDH) and lipogenesis (fatty acid synthase: EC 2.3.1.85; Lc FAS, stearoyl-CoA desaturase: EC 1.14.19.1; Lc SCD) and ATP citrate lyase (EC 2.3.3.8; Lc acyl)) were between 5 and 11 fold less abundant than transcripts regulating glucose production. Transcript levels of $L c$ GLUD1 were approximately 4-fold higher than those of the other amino acid aminotransferase genes (alanine aminotransferase: EC 2.6.1.2; Lc cALAT, and aspartate aminotransferase: EC 2.6.1.1; Lc ASAT). The changes in gene expression were rapid, and the expression of the majority of the genes peaked 2 hours after a meal (Figure 2). Interestingly, this coincided with the peak of plasma glucose and plasma free amino acids at 2 hours after a meal. Also at this time, the glycolytic and lipogenic genes $L c G K$ and $L c S C D$ were the most highly expressed, respectively, and exceeded the relative levels of expression of $L c$ G6Pase (Figure 1). 


\section{Changes in Gene Expression Induced by Feeding}

The relative response of each gene to a meal was calculated for each gene independently using raw cycle threshold values for each gene, normalised to Ef1 $\alpha$, relative to the average Ct value for that gene prior to feeding. The glycolytic genes $L c G K$ and $L c P K$ were significantly up-regulated from 2 to 12 hours after a meal (Fig. 2). Meanwhile, the expression of gluconeogenic genes Lc G6Pase and Lc F1,6BPase were significantly repressed after feeding, although the change in Lc FBPase expression was very small (Figure 2). The Lc G6Pase gene was significantly down-regulated from 2 to 12 hours after feeding, resulting in a significant negative correlation between Lc G6Pase and the glycolytic and lipid metabolism genes, as well as plasma free amino acid levels (Figure 3). None of the genes analysed in this study were correlated with either plasma glucose or liver glucose (Figure 3).

As an alternative to glycolysis, the expression of $L c G 6 P D H$ regulates the production of metabolic intermediates through the pentose phosphate pathway. After feeding, the expression of the $L c G 6 P D H$ gene was significantly elevated from 2 to 12 hours after feeding (Figure 2). This was matched by the significant up-regulation of the fatty acid synthesis genes Lc acyl, Lc FAS and Lc SCD over the same period (Figure 2), and resulted in a significant positive correlation between all four of these genes (Figure 3). One known regulator of lipogenesis is the transcription factor sterol regulatory element binding protein 1c (SREBP-1c). Expression of the $L c S R E B P-1 c$ gene was significantly elevated immediately post feeding, and was positively correlated with $L c$ G6PDH, Lc acyl, Lc SCD, Lc PPARa, Lc cALAT, Lc ASAT, Lc CS and Lc pygl expression, as well as TOR and S6 activation (Fig 3).

The opposing pathway to lipogenesis is the breakdown of fatty acids through $\beta$ oxidation, and known to regulate key steps in this pathway in the liver are genes such as carnitine palmitoyltransferase 1A (EC 2.3.1.21; CPT1A) and peroxisome proliferator-activated receptor alpha (PPARa). Although significantly downregulated at 0.5 and 1 hours after a meal, expression of the Lc CPT1A gene was significantly elevated at 4, 8 and 12 hours after feeding and had returned to pre-feeding levels by 24 hours (Figure 2). This expression pattern showed a significant positive correlation with the expression of $L c G K, L c P K, L c G 6 P D H$ and 
Lc FAS and significant negative correlation with the expression of Lc G6Pase and Lc gys2 (Figure 3). Similarly, Lc PPARa expression was significantly elevated at 1 and 2 hours after feeding and significantly repressed at 24 hours (Fig 2), which resulted in significant positive correlations with $L c$ G6PDH, Lc acyl, Lc SREBP-1c, LC ASAT, LC CS and Lc pygl (Fig 3).

In this study we have focussed on some of the genes involved in amino acid inter-conversion and entry into the TCA cycle for energy production. These included the alanine and aspartate aminotransferases (EC 2.6.1.2; Lc CALAT and EC 2.6.1.1; Lc ASAT), glutamate dehydrogenase (EC 1.4.1.2; Lc GLUD1), as well as citrate synthase (EC 2.3.3.1; $L c C S$ ) which is the pace making enzyme of the TCA cycle. Expression of $L c A L A T$ was significantly up-regulated within 0.5 hours of feeding and had returned to normal levels by 8 hours. The change in expression of the other genes $L c A S A T$ and $L c$ glud was only very small after a feeding event, and in most cases this change was not significant. However, the significant upregulation of $L c A S A T$ at 2 and 4 hours after a meal resulted in a positive correlation with $L c G 6 P D H, L c$ acyl and $L c S R E B P-1 c$. In addition, expression levels of pyruvate dehydrogenase kinase (EC 2.7.11.2; $L c P D K$ ) were analysed, and showed a significant decrease between 4 and 12 hours after feeding, that produced strong negative correlations with glycolytic and lipogenic genes.

The expression of the hepatic isoform of the glycogen synthase gene (EC 2.4.1.11; Lc gsy2) was progressively down regulated to a low point 12 hours after feeding (Figure 3). This caused Lc gys2 expression to be significantly negatively correlated with $L c P K$ and $L c$ CPT1A. The glycogen phosphorylase gene (EC 2.4.1.1; Lc pygl) was significantly up-regulated after feeding, and peaked 12 hours after feeding. The Lc pygl expression showed a significant positive correlation with the expression of lipid synthesis genes ( $L c$ acyl, Lc FAS and Lc SREBP-1c) as well as the expression of $L c P P A R a, L c G 6 P D H$ and LC ASAT. Although they appeared complementary in their post feeding expression pattern, there was no significant negative correlation between Lc gys2 and Lc pygl.

\section{Signalling Pathways}

The activity of members of the mTOR signalling cascade were assessed by quantifying the ratio between the phosphorylated and unphosphorylated form of each enzyme. There was a significant activation of the insulin signalling cascade, 
where the phosphorylated form of each protein was significantly more abundant after feeding (Figure 4). Phosphorylation of barramundi Akt, TOR and S6 significantly increased at least $30 \mathrm{~min}$ after the meal and remained elevated until 4 hours after feeding. Positive correlations were observed between Akt, mTOR and S6, as well as the other genes $L c S R E B P-1 c, L c c A L A T$ and, in the case of S6, Lc CS (Figure 3). 


\section{Discussion}

The barramundi in this study showed the ability to effectively regulate blood glucose levels, since plasma glucose reached a maximum value $2 \mathrm{~h}$ after refeeding but returned to basal level at the most $2 \mathrm{~h}$ after that. This result was as expected given the diet was only composed of $11 \%$ total carbohydrates, of which was approximately 30\% digestible to barramundi (Glencross et al. 2012). The result of this study mimicked the peak in plasma glucose levels at 2 hours postfeeding recorded previously in this species when using a diet containing $30 \%$ pre-gelatinised starch that is known to be poorly utilised in this species (Allan et al. 2003). However, in the same study, including high levels of highly digestible glucose in the diet (up to $30 \%$ ) or intraperitoneal injection of over $1 \mathrm{~g} \mathrm{~kg}^{-1}$ of glucose caused pronounced elevation of plasma glucose levels for at least 8 hours (Allan et al. 2003). The present study demonstrated that there was no persistent post-feeding hyperglycaemia using a diet that is composed of $50 \%$ digestible protein energy, 15\% lipid energy and approximately 3\%, carbohydrate energy. The response to feeding this nutritionally optimised diet enabled the analysis of how these fish are able to metabolise dietary energy and how these processes are regulated at the molecular level.

Although provided at low levels in the diet in this study, the mechanism by which barramundi utilise dietary carbohydrates appears to be very different to other fish species, despite its carnivorous status. Glucokinase (GK) and pyruvate kinase $(\mathrm{PK})$ are the two first enzymes involved in hepatic glucose utilization, along with the entry of glycolytic pyruvate to the TCA cycle via the pyruvate dehydrogenase complex (PDC). The ability of barramundi to rapidly and simultaneously upregulate $L c G K, L c P K$ and down-regulate Lc G6Pase and $L c P D K$ may underlie the metabolism of dietary carbohydrates in this species. The rapid induction of $L c G K$ and $L c P K$ gene expression during the first 2 hours following the meal is consistent with the ability of barramundi to metabolise simple carbohydrates, although the response of these genes at higher carbohydrate levels has not been investigated to date. Induction of glucokinase after feeding has been reported in a number of fish species (Panserat et al. 2001; Méton et al. 2004), as well as in response to increased levels of dietary carbohydrates (Panserat et al. 2000). However, the regulation of $L c P K$ gene expression in barramundi after a meal 
seems to be closer to that observed in mammalian species, rather than in other fish. In mammals, regulation of PK occurs at both transcriptional and posttranscriptional levels (Assimacopoulos-Jeannet and Jeanrenaud 1990), whereas $P K$ gene expression has been shown to be poorly regulated in trout (Panserat et al. 2001; Skiba-Cassy et al. 2009).

In some fish species, such as trout, the lack of post-prandial G6Pase repression has also been proposed to be a contributing factor towards the prolonged elevation of plasma glucose levels (Panserat et al., 2001). Some fish, such as trout and sea bream, have shown the ability to reduce G6Pase expression in response to dietary post-feeding (Caseras et al. 2002; Méton et al. 2004; Saldago et al. 2004; Meningen et al., 2012), but not until 4-8 hours after the feeding event. Barramundi in this study showed the ability to down-regulate LcG6Pase expression within 2 hours after a meal, a result consistent with the low metabolic requirement for endogenous glucose production while it is available at low levels in the diet. Where both gene expression and enzyme activity have been studied, G6pase expression is often linked to G6Pase enzyme activity (Caseras et al. 2002; Méton et al. 2004; Saldago et al. 2004). However, down regulation of G6Pase gene expression does not automatically mean inhibition of gluconeogenesis, as a recent study performed in trout showed a post-prandial inhibition of G6Pase gene expression was not linked to the modification of G6Pase enzyme activity (Skiba-Cassy et al., 2012).

Expression of Lc CALAT was observed to significantly increase immediately after feeding. This enzyme product of this gene functions to link carbohydrate and amino acid metabolism, and increased ALAT activity is connected with enhanced gluconeogenesis and fasting (Méton et al. 1999; Fernandez et al. 2007; PérezJiménez et al. 2012). In fish studied to date, including trout and seabream, one mitochondrial form ( $m A L A T$ ) and two cytosolic isoforms (cALAT1 and cALAT2) have been identified (Méton et al. 2004; Fernandez et al. 2007; Anaemet et al. 2008). In addition, cALAT1 was shown to be the predominant isoform in liver tissue, and the two cytosolic isoforms were independently regulated in response to nutrients, whereby starvation decreased cALAT1 expression, and refeeding increased $C A L A T 1$ expression and decreased $C A L A T 2$ expression (Anaemet et al. 2008). Unfortunately, it is not known if barramundi possess these two cALAT 
isoforms, as the sequence of the LC CALAT gene analysed in this study is shared by both isoforms. However, if the mechanism of cALAT regulation was conserved between barramundi and sea bream, it is likely that the barramundi sequence corresponds to the cALAT1 isoform. Whether two cALAT isoforms exist in barramundi requires clarification, with important implications for the use of analysing gene expression in response to nutrients.

Pyruvate dehydrogenase kinase (PDK) phosphorylates and inactivates the pyruvate dehydrogenase complex (PDC), a group of enzymes that converts pyruvate to acetyl-CoA as an entry point into the TCA cycle. The expression of $L c$ PDK was lowest 4 hours after a meal, suggesting that there was also an increase in both the activity of the PDC and potentially the entry of metabolic intermediates into the TCA cycle. Since the PDC is active during metabolism of metabolic intermediates generated through glycolysis, as well as gluconeogenic amino acids such as alanine, serine and glycine, it is not possible to distinguish the proportion of energy metabolism derived from glycolysis or amino acid metabolism. Something about CS here...... The results of this study demonstrate that measuring $L c P D K$ gene expression may be used to assess the activation of the PDC and hence the entry of metabolic intermediates to the TCA cycle. Similarly, Lc CS expression may reflect the timing of energy production through the TCA cycle after a meal is consumed.

The mammalian target of rapamycin (mTOR) is a central controller of the growth in response to nutrients, growth factors and cellular energy status (Polak et al. 2009; Wullschleger et al. 2006). Recent studies performed in mammals and fish indicate that TOR signalling pathway controls de novo lipogenesis by regulating the expression and processing of sterol regulatory element-binding protein 1c (SREBP1c), a master regulator of sterol- and lipogenic gene transcription (Dentin et al 2005; Duvel et al. 2010; Eberle et al. 2004; Lansard et al., 2010; Seiliez et al. 2011). Genes that code the enzymes glucokinase (GK), ATP-citrate lyase (acyl), acetyl-CoA carboxylase (ACC) and fatty acid synthase (FAS) have been thus identified as targets of the transcription factor SREBP-1c (Girard et al. 1997; Kim 2004; Portsmann et al. 2008; Sato 2000; Skiba-Cassy et al., 2009). In this study, we observed strong correlations between the activation of the mTOR signaling pathway, LC SREBP-1c expression and glycolysis ( $L C G K$ 
and $L c P K$ ), the pentose phosphate pathway ( $L c$ G6PDH) and lipogenic gene expression ( $L c$ acyl, Lc FAS and LC SCD). As such, our data confirm the link between the mTOR pathway and $S R E B P-1 C$ as the master regulator of fatty acid and triglyceride synthesis in barramundi, resulting in increased expression of glycolytic and lipogenic genes. Whereas Akt phosphorylation is mainly controlled by insulin in trout, in vivo activation of the mTOR pathway seems to require both insulin and amino acids (Avruch et al., 2009; Lansard et al 2010 and 2011; Seiliez et al. 2011). We observed a small increase in circulating free amino acids in the plasma that coincided with the activation of the mTOR pathway, but this was not significantly correlated. Although likely to be the same as other species, further studies are required to confirm the role of amino acids in the regulation of the TOR signalling pathway in barramundi.

Expression of genes regulating $\beta$-oxidation in barramundi were in stark contrast to the response seen in fish, mammalian and avian species. Fasting has been shown to be a potent activator of $\beta$-oxidation in the liver (Escher et al. 2001; Leaver et al. 2005). As such, refeeding has been shown to significantly down regulate $\underline{C P T 1 A}$ expression, as well as the expression of the master regulator of hepatic lipid catabolism, PPAR $\alpha$ (Leaver et al. 2005; Meningen et al., 2012). However, in barramundi both $L c C P T 1 A$ and $L c P P A R \alpha$ were elevated over a prolonged period after refeeding. These results imply that the lipolytic pathway, along with the glycolytic and lipogenic pathways, are for some reason active at the same time, or that one of these pathways is perhaps constitutively active or poorly regulated. One potential explanation is that certain classes of polyunsaturated fatty acids (PUFAs), particularly n-3 and n-6, are known to act as direct ligands to activate PPAR $\alpha$ and hence other fatty acid oxidation genes (Keller et al., 1993; Clarke 2000). In a similar way, supply of dietary n-3 and n-6 PUFAs may also be triggering fatty acid catabolism through PPAR $\alpha$ in barramundi, although this requires further confirmation through other genes targets such as acyl Co-A oxidase. What remains clear is that the pathways that modulate fatty acid oxidation in barramundi are nutritionally regulated, and that PPAR $\alpha$ and downstream targets of $\operatorname{PPAR} \alpha$ are involved in fatty acid catabolism in barramundi. 
The results of the glycogen gene expression data were also counter intuitive, in that glycogen breakdown appeared to be occurring at times when glucose and energy were abundant, since the expression of the glycogen synthase gene underwent a continuous decrease during the 12 hours following the meal. In general, an increase in liver glycogen has been observed once fish are refed after periods of starvation, or in response to elevated dietary carbohydrates (Enes et al. 2011, 2012; Figueiredo-Garutti et al. 2002; Leung and Woo 2011; Panserat and Kaushik 2010; Viegas et al. 2012), including barramundi (Allan et al. 2003). Glycogen is not thought to be a major contributor to the storage of excess energy in fish, and glycogen metabolism is known to be rapidly modified by allosteric effects and phosphoregulation (NRC 2011). At the very least, the data from the present study indicate that in barramundi the expression of genes controlling glycogen turnover is regulated by nutritional status, but may not be suitable markers of glycogen regulation. Genes that regulate phosphorylation events controlling glycogenesis, such as glycogen synthase kinase, may be more suitable molecular targets.

Although these types of functional genetic correlations performed in this study do not indicate that these genes are directly co-regulated, they do provide an indication of the trends that may be occurring in the regulation of various nutritional pathways. A higher degree of confidence in biological function could be attributed to some of the gene expression responses if a corresponding change in enzyme activity was also confirmed. Most often, the focus of current studies of fish intermediary metabolism is directed towards the modification of gene expression in response to modifying dietary energy sources, particularly protein and carbohydrate levels. It is paramount that this type of nutritional regulation be interpreted in conjunction with knowledge of how different species genes that regulate intermediary metabolism are regulated in the hours after feeding. Differences in the timing of activation of, or the ability to regulate, specific metabolic pathways may play a central role in the metabolic consequences of dietary nutrient utilisation for each different fish species. 


\section{Acknowledgements}

This work was supported by a grant from the Australian Centre for International Agricultural Research (ACIAR) project FIS-2006-141. We gratefully acknowledge the review of a draft of this manuscript by Katherine Morton. 
References

Allan GL, Booth M, Stone DAJ, Anderson A (2003) Aquaculture Diet Development Subprogram: Ingredient Evaluation (No. FRDC 1996/391). NSW Fisheries Final Report Series.

Assimacopoulos-Jeannet F, Jeanrenaud B (1990) Insulin activates 6phosphofructo-2-kinase and pyruvate kinase in the liver. Indirect evidence for an action via a phosphatase. J Biol Chem 265, 7202-7206.

Avruch J, Long X, Ortiz-Vega S, Rapley J, Papageorgiou A, Dai N (2009) Amino acid regulation of TOR complex 1. Am. J. Physiol. Endocrinol. Metab. 296, E592602.

Azevedo PA, Cho CY, Leeson S, Bureau DP (1998) Effects of feeding level and water temperature on growth, nutrient and energy utilization and waste outputs of rainbow trout (Oncorhynchus mykiss). Aquat Living Resour 11: 227-238. Bergot F, Breque J (1983) Digestibility of starch by rainbow trout: effects of the physical state of starch and the intake level. Aquaculture 34: 203-212. Caseras A, Meton I, Fernandez F, Baanante IV (2000) Glucokinase gene expression is nutritionally regulated in liver of gilthead sea bream (Sparus aurata). Biochim Biophys Acta 1493: 135-141.

Caseras A, Méton I, Vives C, Egea M, Fernandez F, Baanante IV (2002) Nutritional regulation of glucose-6-phosphatase gene expression in liver of the gilthead sea bream (Sparus aurata). Br J Nutr 88: 607.

Catacutan MR, Coloso RM (1997) Growth of juvenile Asian seabass, Lates calcarifer, fed varying carbohydrate and lipid levels. Aquaculture 149: 137-144. Craig PM, Moon TW (2011) Fasted zebrafish mimic genetic and physiological responses in mammals: a model for obesity and diabetes? Zebrafish 8: 109-117. Degger B, Upton Z, Soole K, Collet C, Richardson N (2000) Comparison of recombinant barramundi and human insulin-like growth factor (IGF)-I in juvenile barramundi (Lates calcarifer): in vivo metabolic effects, association with circulating IGF-binding proteins, and tissue localisation. Gen Comp Endocrinol 117: 395-403.

Dentin R, Girard J, Postic C (2005) Carbohydrate responsive element binding protein (ChREBP) and sterol regulatory element binding protein-1c (SREBP-1c): 
two key regulators of glucose metabolism and lipid synthesis in liver. Biochimie 87: 81-86.

De Santis C, Smith-Keune C, Jerry DR (2011) Normalizing RT-qPCR data: are we getting the right answers? An appraisal of normalization approaches and internal reference genes from a case study in the Finfish Lates calcarifer. Mar Biotechnol 13: 170-180.

Düvel KK, Yecies JJ, Menon SS, Raman PP, Lipovsky AA, Souza AA, Triantafellow EE, Ma QQ, Gorski RR, Cleaver SS, Vander Heiden MM, MacKeigan JJ, Finan PP, Clish CC, Murphy LL, Manning BB (2010) Activation of a Metabolic Gene Regulatory Network Downstream of mTOR Complex 1. Mol Cell 39, 13-13. Dyer AR, Barlow CG, Bransden MP, Carter CG, Glencross BD, Richardson N, Thomas PM, Williams KC, Carragher JF (2004) Correlation of plasma IGF-I concentrations and growth rate in aquacultured finfish: A tool for assessing the potential of new diets. Aquaculture 236: 583-592.

Eberlé D, Hegarty B, Bossard P, Ferré P, Foufelle F (2004) SREBP transcription factors: master regulators of lipid homeostasis. Biochimie 86, 839-848.

Enes P, Peres H, Couto A, Oliva-Teles A (2010) Growth performance and metabolic utilization of diets including starch, dextrin, maltose or glucose as carbohydrate source by gilthead sea bream (Sparus aurata) juveniles. Fish Physiol Biochem 36: 903-910.

Enes P, Panserat S, Kaushik S, Olivateles A (2008) Growth performance and metabolic utilization of diets with native and waxy maize starch by gilthead sea bream (Sparus aurata) juveniles. Aquaculture 274: 101-108.

Enes P, Pousão-Ferreira P, Salmerón C, Capilla E, Navarro I, Gutierrez J, OlivaTeles A (2012) Effect of guar gum on glucose and lipid metabolism in white sea bream Diplodus sargus. Fish Physiol Biochem. doi: 10.1007/s10695-012-9687-0 Escher PP, Braissant 00, Basu-Modak SS, Michalik LL, Wahli WW, Desvergne BB (2001) Rat PPARs: quantitative analysis in adult rat tissues and regulation in fasting and refeeding. Endocrinol 142: 4195-4202.

Figueiredo-Garutti MM, Navarro II, Capilla EE, Souza RR, Moraes GG, Gutiérrez JJ, Vicentini-Paulino MM (2002) Metabolic changes in Brycon cephalus (Teleostei, Characidae) during post-feeding and fasting. Comp Biochem Physiol A 132: 467476. 
Fisher G, Arias I, Quesada I, D'Aniello S, Errico F, Di Fiore M, D'Aniello A (2001) A fast and sensitive method for measuring picomole levels of total free amino acids in very small amounts of biological tissues. Amino Acids 20: 163-173.

Gatlin DM, Barrows FT, Brown P, Dabrowski K, Gaylord TG, Hardy RW, Herman E, Hu G, Krogdahl A, Nelson R, Overturf K, Rust M, Sealy W, Skonberg D, Souza EJ, Stone D, Wilson R, Wurtele E (2007) Expanding the utilisation of sustainable plant products in aquafeeds: a review. Aquacult. Res. 38: 551-579.

Girard J, Ferré P, Foufelle F (1997) Mechanisms by which carbohydrates regulate expression of genes for glycolytic and lipogenic enzymes. Annu Rev Nutr 17: 325-352.

Glencross B (2006) The nutritional management of barramundi, Lates calcarifer a review. Aquacult Nutr 12: 291-309.

Glencross BD, Hawkins WE, Evans D, McCafferty P, Dods K Sipsas S (2007) Heat damage during some drying techniques affects nutrient utilisation, but not digestibility of lupin protein concentrates fed to rainbow trout, Oncorhynchus mykiss. Aquaculture 265: 218-229.

Glencross BD, Booth M, Allan GL (2007) A feed is only as good as its ingredients A review of ingredient evaluation for aquaculture feeds. Aquaculture Nutr 13: 17-34.

Glencross B, Rutherford N, Hawkins W (2011a) A comparison of the growth performance of rainbow trout (Oncorhynchus mykiss) when fed soybean, narrowleaf or yellow lupin meals in extruded diets. Aquacult Nutr 17: E317-E325. Glencross B, Hawkins W, Evans D, Rutherford N, McCafferty P, Dods K, Hauler R (2011b). A comparison of the effect of diet extrusion or screw-press pelleting on the digestibility of grain protein products when fed to rainbow trout (Oncorhynchus mykiss). Aquaculture 312: 154-161.

Glencross B, Rutherford N, Jones B (2011c) Evaluating options for fishmeal replacement in diets for juvenile barramundi (Lates calcarifer). Aquacult Nutr 17: E722-E732.

Glencross BD, Blyth D, Tabrett SJ, Bourne N, Irvin S, Fox-Smith T, Smullen RP (2012) An examination of digestibility and technical qualities of a range of cereal grains when fed to juvenile barramundi (Lates calcarifer) in extruded diets. Aquaculture Nutr 18: 388-399. 
Green MR, Sambrook J (2012). Molecular cloning : a laboratory manual, 4th ed.

Cold Spring Harbour Laboratory Press, New York.

Hemre G-I, Mommsen TP, Krogdahl A (2002) Carbohydrates in fish nutrition:

effects on growth, glucose metabolism and hepatic enzymes. Aquac Nutr 8: 175194

Jeong KS, Takeuchi T, Watanabe T (1991) Improvement of nutritional quality of carbohydrate ingredients by extrusion processes in diets of red seabream.

Nippon Suisan Gakkaishi 57: 1543-1549.

Kamalam BS, Médale F, Kaushik S, Polakof S, Skiba-Cassy S, Panserat S (2012)

Regulation of metabolism by dietary carbohydrates in two lines of rainbow trout divergently selected for muscle fat content. J Exp Biol 215: 2567-2578.

Kaushik SJ (1998) Nutritional bioenergetics and estimation of waste production in non-salmonids. Aquat. Living Resour 11: 311-318.

Lupatsch I, Kissil G W, Sklan D (2001) Optimization of feeding regimes for

European sea bass Dicentrarchus labrax: a factorial approach. Aquaculture 202: 289-302.

Keller H, Dreyer C, Medin J, Mahfoudi A, Ozato K, Wahli W (1993) Fatty acids and retinoids control lipid metabolism through activation of peroxisome proliferator-activated receptor-retinoid X receptor heterodimers. Proc Natl Acad Sci 90: 2160-2164.

Kim S-Y, Kim H-I, Kim T-H, Im S-S, Park S-K, Lee I-K, Kim K-S, Ahn Y-H (2004) SREBP-1c Mediates the insulin-dependent hepatic glucokinase expression. J Biol Chem 279, 30823-30829.

Lansard M, Panserat S, Plagnes-Juan E, Seiliez I, Skiba-Cassy S (2010) Integration of insulin and amino acid signals that regulate hepatic metabolism-related gene expression in rainbow trout: role of TOR. Amino Acids 39: 801-810.

Lansard M, Panserat S, Plagnes-Juan E, Dias K, Seiliez I, Skiba-Cassy S (2011) Lleucine, L-methionine, and L-lysine are involved in the regulation of intermediary metabolism-related gene expression in rainbow trout hepatocytes. J. Nutr. 141: 75-80.

Leaver MJ, Boukouvala E, Antonopoulou E, Diez A, Favre-Krey L, Ezaz MT, Bautista JM, Tocher DR, Krey G (2005) Three peroxisome proliferator-activated 
receptor isotypes from each of two species of marine fish. Endocrinol 146: 31503162.

Leung LY, Woo NS (2012) Influence of dietary carbohydrate level on endocrine status and hepatic carbohydrate metabolism in the marine fish Sparus sarba. Fish Physiol Biochem 38: 543-554.

Marshall OJ (2004) PerlPrimer: cross-platform, graphical primer design for standard, bisulphite and real-time PCR. Bioinformatics 20: 2471-2472. Mennigen JA, Panserat S, Larquier M, Plagnes-Juan E, Médale F, Seiliez I, SkibaCassy S (2012) Postprandial regulation of hepatic microRNAs predicted to target the insulin pathway in rainbow trout. Plos One 7: e38604.

Méton I, Caseras A, Fernandez F, Baanante IV (2004) Molecular cloning of hepatic glucose-6-phosphatase catalytic subunit from gilthead sea bream (Sparus aurata): response of its mRNA levels and glucokinase expression to refeeding and diet composition. Comp Biochem \& Physiol B 138: 145-153.

Moon T (2001). Glucose intolerance in teleost fish: fact or fiction? Comp Biochem Phys B 129: 243-249.

National Research Council (NRC). Nutrient Requirements of Fish and Shrimp. Washington DC: National Academy Press; 2011.

Olsvik PAP, Lie KKK, Jordal A-EOA, Nilsen TOT, Hordvik II (2004) Evaluation of potential reference genes in real-time RT-PCR studies of Atlantic salmon. BMC Mol Biol 6: 21-21.

Panserat S, Médale F, Blin C, Brèque J, Vachot C, Plagnes-Juan E, Gomes E, Krishnamoorthy R, Kaushik S (2000) Hepatic glucokinase is induced by dietary carbohydrates in rainbow trout, gilthead seabream, and common carp. Am. J. Physiol 278: R1164-70.

Panserat S, Capilla E, Gutierrez J, Frappart PO, Vachot C, Plagnes-Juan E, Aguirre P, Brèque J, Kaushik S (2001) Glucokinase is highly induced and glucose-6phosphatase poorly repressed in liver of rainbow trout (Oncorhynchus mykiss) by a single meal with glucose. Comp Biochem Physiol B 128: 275-283.

Panserat S, Plagnes-Juan E, Brèque J, Kaushik S (2001) Hepatic phosphoenolpyruvate carboxykinase gene expression is not repressed by dietary carbohydrates in rainbow trout (Oncorhynchus mykiss). J Exp Biol 204: 359-365. 
Panserat S, Skiba-Cassy S, Seiliez I, Lansard M, Plagnes-Juan E, Vachot C, Aguirre P, Larroquet L, Chavernac G, Médale F, Corraze G, Kaushik S, Moon TW (2009) Metformin improves postprandial glucose homeostasis in rainbow trout fed dietary carbohydrates: a link with the induction of hepatic lipogenic capacities? Am J Physiol Regul Integr Comp Physiol 297: R707-R715.

Panserat S, Kaushik SJ (2010) Regulation of gene expression by nutritional factors in fish. Aquac Res 41: 751-762.

Pérez-Jiménez A, Cardenete G, Hidalgo MC, García-Alcázar A, Abellán E, Morales AE (2012) Metabolic adjustments of Dentex dentex to prolonged starvation and refeeding. Fish Physiol Biochem 38: 1145-1157.

Polak P, Hall MN, (2009) mTOR and the control of whole body metabolism. Curr Opin Cell Biol 21: 209-218.

Polakof S, Panserat S, Soengas JL, Moon TW (2012) Glucose metabolism in fish: a review. J Comp Physiol B 182: 1015-1045.

Porstmann T, Santos CR, Griffiths B, Cully M, Wu M, Leevers S, Griffiths JR, Chung Y-L, Schulze A (2008) SREBP activity is regulated by mTORC1 and contributes to Akt-dependent cell growth. Cell Metabolism 8: 224-236.

Resuehr D, Spiess A-N (2003) A real-time polymerase chain reaction-based evaluation of cDNA synthesis priming methods. Anal Biochem 322: 287-291. Salgado MC, Meton I, Egea M, Baanante IV (2004) Transcriptional regulation of glucose-6-phosphatase catalytic subunit promoter by insulin and glucose in the carnivorous fish, Sparus aurata. J Mol Endocrinol 33: 783-795.

Sato R (2010) Sterol metabolism and SREBP activation. Arch Biochem Biophys 501: 177-181.

Seiliez I, Gabillard JC, Skiba-Cassy S, Garcia-Serrana D, Gutierrez J, et al. (2008) An in vivo and in vitro assessment of TOR signaling cascade in rainbow trout (Oncorhynchus mykiss). Am J Physiol Regul Integr Comp Physiol 295: R329-335. Seiliez I, Panserat S, Lansard M, Polakof S, Plagnes-Juan E, Surget A, Dias K, Larquier M, Kaushik S, Skiba-Cassy S (2011) Dietary carbohydrate-to-protein ratio affects TOR signaling and metabolism-related gene expression in the liver and muscle of rainbow trout after a single meal. Am J Physiol Regul Integr Comp Physiol 300: R733-43. 
Skiba-Cassy S, Lansard M, Panserat S, Médale F (2009) Rainbow trout genetically selected for greater muscle fat content display increased activation of liver TOR signaling and lipogenic gene expression. Am J Physiol Regul Integr Comp Physiol 297: R1421-9.

Skiba-Cassy S, Panserat S, Larquier M, Dias K, Surget A, Plagnes-Juan E, Kaushik S, Seiliez I (2012) Apparent low ability of liver and muscle to adapt to variation of dietary carbohydrate:protein ratio in rainbow trout (Oncorhynchus mykiss). Br J Nutr doi:10.1017/S0007114512003352.

Stone D (2003) Dietary carbohydrate utilization by fish. Rev Fish Sc 11: 337-369. Srivastava AK, Pandey SK (1998) Potential mechanism(s) involved in the regulation of glycogen synthesis by insulin. Mol Cell Biochem 182: 135-141.

Viegas II, Rito JJ, Jarak II, Leston SS, Carvalho RR, Metón II, Pardal MM, Baanante II, Jones JJ (2012) Hepatic glycogen synthesis in farmed European seabass (Dicentrarchus labrax L.) is dominated by indirect pathway fluxes. Comp Biochem Physiol A 163: 22-29.

Wilson R (1994) Utilization of Dietary Carbohydrate by Fish. Aquaculture, 124: 67-80.

Wullschleger SS, Loewith RR, Hall MM (2006) TOR Signaling in Growth and Metabolism. Cell 124: 471-484. 
Table 1 The ingredient formulation and nutritional composition of experimental diet. All values are $\mathrm{g} \mathrm{kg}^{-1}$ dry matter (DM) unless otherwise detailed.

\section{Ingredient Formulation $\left(\mathrm{g} \mathrm{kg}^{-1}\right)$}

Yttrium oxide

Pre-mix vitamins*

Fish oil

Wheat gluten

100.0

Wheat flour

145.0

Fish meal

\section{Diet nutritional composition}

Dry matter

Crude protein

Digestible protein

Lipid

Carbohydrate

Phosphorus

Ash

Gross energy ( $\left.\mathrm{MJ} \mathrm{kg}^{-1} \mathrm{DM}\right)$

Lysine

Threonine

19.71

Methionine

13.20

Isoleucine

22.66

Leucine

Tryptophan

Valine

Phenylalanine

20.90

Histidine

10.84

Arginine

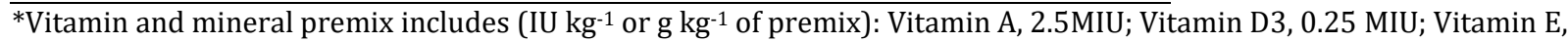
16.7 g; Vitamin K,3, 1.7 g; Vitamin B1, 2.5 g; Vitamin B2, 4.2 g; Vitamin B3, 25 g; Vitamin B5, 8.3; Vitamin B6, 2.0 g; Vitamin B9, 0.8; Vitamin B12, 0.005 g; Biotin, 0.17 g; Vitamin C, 75 g; Choline, 166.7 g; Inositol, 58.3 g; Ethoxyquin, 20.8 g; Copper, 2.5 g; Ferrous iron, 10.0 g; Magnesium, 16.6 g; Manganese, 15.0 g; Zinc, 25.0 g. 
Table 2. Target genes of intermediary metabolism in barramundi, and the primer sequences used to analyse their expression.

\begin{tabular}{|c|c|c|c|c|c|c|}
\hline Target Gene & $\begin{array}{c}\text { Gene } \\
\text { Abbreviation }\end{array}$ & EC Number & $\begin{array}{c}\text { Genbank } \\
\text { Accession }\end{array}$ & Primer Name & Sequence & Length \\
\hline \multicolumn{7}{|l|}{ Glucose Metabolism } \\
\hline \multirow{2}{*}{ Glucokinase (Hexokinase IV) } & \multirow{2}{*}{$L c G K$} & \multirow{2}{*}{ EC 2.7.1.1 } & & GK qPCR.For 2 & CTGGTGTGATCAACCGAATG & 20 \\
\hline & & & & GK pPCR.Rev 2 & АССАСТССССТССТСТGАСТ & 20 \\
\hline \multirow{2}{*}{ Glucose-6-Phosphatase } & \multirow{2}{*}{ Lc G6Pase } & \multirow{2}{*}{ EC 3.1.3.9 } & & G6Pase qPCR.For 1 & TTGCTGGTGTCATCACAGGT & 20 \\
\hline & & & & G6Pase qPCR.Rev 1 & CACTTCTGGGCTTTCTCCAG & 20 \\
\hline \multirow{2}{*}{ Fructose-1,6-Bisphosphatase } & \multirow{2}{*}{ Lc F1,6BPase } & \multirow{2}{*}{ EC 3.1.3.11 } & & F1,6BPaseqPCR.For 1 & GATATGTTGGTTCAATGGTGGCT & 23 \\
\hline & & & & F1,6BPaseqPCR.Rev 1 & GGACTCGTTGGTGGATTGTG & 20 \\
\hline \multirow{2}{*}{ Pyruvate Kinase } & \multirow{2}{*}{$L c P K$} & \multirow{2}{*}{ EC 2.7.1.40 } & & PK qPCR.For 2 & TCACGCСТСТСТССТCTGAT & 20 \\
\hline & & & & PK qPCR.Rev 2 & TTCTGGTGACCGCAATGATA & 20 \\
\hline Glucose-6-Phosphate & \multirow{2}{*}{ Lc G6PDH } & \multirow{2}{*}{ EC 1.1.1.49 } & & G6PDH qPCR F1 & САAАCTCAACACACACATCC & 20 \\
\hline Dehydrogenase & & & & G6PDH qPCR R1 & СTTCTCTACAATCACCCTGTTC & 22 \\
\hline \multicolumn{7}{|l|}{ Fatty Acid Metabolism } \\
\hline \multirow{2}{*}{ Fatty Acid Synthase } & \multirow{2}{*}{ LC FAS } & \multirow{2}{*}{ EC 2.3.1.85 } & & FAS qPCR.For 1 & TGAATCTCACCACGCTTCAG & 20 \\
\hline & & & & FAS qPCR.Rev 1 & AGGCAGCAATAGAACCCTCA & 20 \\
\hline \multirow{2}{*}{ Stearoyl CoA Desaturase } & \multirow{2}{*}{ LC SCD } & \multirow{2}{*}{ EC 1.14.19.1 } & & SCD qPCR.For 1 & CCTGGTACTTCTGGGGTGAA & 20 \\
\hline & & & & SCD qPCR.Rev 1 & AAGGGGAATGTGTGGTGGTA & 20 \\
\hline \multirow{2}{*}{ CarnitinePalmitoyltransferase } & \multirow{2}{*}{ Lc CPT1A } & \multirow{2}{*}{ EC 2.3.1.21 } & & CPT1A qPCR.For 1 & TGATGGTTATGGGGTGTCCT & 20 \\
\hline & & & & CPT1A qPCR.Rev 1 & CGGCTCTCTTCAACTTTGCT & 20 \\
\hline \multirow{2}{*}{ ATP Citrate Lyase } & \multirow{2}{*}{ Lcacyl } & \multirow{2}{*}{ EC 2.3.3.8 } & & Lcal acyl F1 & CAACACCATTGTCTGTGCTC & 20 \\
\hline & & & & Lcal acyl R1 & GAAATGCTGCTTAACAAAGTCC & 21 \\
\hline \multirow{2}{*}{$\begin{array}{l}\text { Sterol Regulatory Element } \\
\text { Binding Protein }\end{array}$} & \multirow{2}{*}{ LC SREBP-1c } & $n ?$ & & Lcal SREBP F2 & GTTCTGGGTGTGCATATTGC & 20 \\
\hline & & na & & Lcal SREBP R2 & GGATCAGAACTCCAGACACC & 20 \\
\hline Amino Acid Metabolism & & & & & & \\
\hline Alanine Aminotransferase, & $I S \subset A I A T$ & $\mathrm{~F} C 2612$ & & cALATqPCR.For 2 & GATGAACCСТCCTACACCAC & 20 \\
\hline cytosolic form & LC CALAT & EC 2.6.1.2 & & cALATqPCR.Rev 2 & TTTGAGGTAGAGTGATGCGG & 20 \\
\hline$\Delta$ cnartate $\Delta$ minotrancforace & $I C A S A T$ & $F C 2611$ & & ASAT qPCR.For 1 & CATTCGCTTCTTCGTCTCTG & 20 \\
\hline Aspartate Ammotransierase & $L C A D A T$ & EL 2.6.1.1 & & ASAT qPCR.Rev 1 & TCCTGACAATCTTCTCСАTCTG & 22 \\
\hline Glutamate Dehydrogenase & Ic GLULD1 & $\mathrm{FC} 1412$ & & Glud qPCR.For 1 & GGATATTGTTCACTCTGGGTTGG & 23 \\
\hline & LC ULUDI & LC 1.4 .1 .2 & & Glud qPCR.Rev 1 & GAAGTGTGGGTCGTGATTGG & 20 \\
\hline Glycogen Metabolism & & & & & & \\
\hline Glycogen Synthase, liver & Lc gys2 & EC 2.4.1.11 & & Lcal gys2 F2 & CAAGATTCCCATGGCAACAG & 20 \\
\hline
\end{tabular}


isoform

Glycogen Phosphorylase, liver isoform

Control Genes

Luciferase

Elongation Factor 1 alpha
Lc pygl

EC 2.4.1.1

Luc

Lc Ef1 $\alpha$
Lcal gys2 R2

Lcal pygl F2

Lcal pygl R2

Luc qPCR For

Luc qPCR Rev

Lcal Ef1 $\alpha$ F

Lcal Ef1 $\alpha$ R
AGACTGTGGTGAAGACATGAG

CACACTCCAAGACATCATCC

GTCCACAAAGATTCTCATCAG

GGTGTTGGGCGCGTTATTTA

CGGTAGGCTGCGAAATGC

AAATTGGCGGTATTGGAAC

GGGAGCAAAGGTGACGAC
21

21

20

18

19 
Table 3. Plasma and tissue chemistry parameters

\begin{tabular}{lccccccccc}
\hline Parameter & Units & T0 & T0.5 & T1 & T2 & T4 & T8 & T12 & T24 \\
\hline & & & & & & & & & \\
Plasma & & $5.1 \mathrm{ab}$ & $6.1 \mathrm{ab}$ & $6.4 \mathrm{ab}$ & $7.5 \mathrm{~b}$ & $5.8 \mathrm{ab}$ & $4.4 \mathrm{a}$ & $3.4 \mathrm{a}$ & $4.8^{\mathrm{a}}$ \\
Glucose & mmolL $^{-1}$ & \pm 1.0 & \pm 1.0 & \pm 1.1 & \pm 0.4 & \pm 0.5 & \pm 0.6 & \pm 0.3 & \pm 1.0 \\
Liver & $\mu$ molL- & 7.4 & 6.8 & 7.9 & 8.4 & 7.4 & 8.2 & 7.6 & 8.4 \\
Glucose & 1 & \pm 0.4 & \pm 0.4 & \pm 0.3 & \pm 0.3 & \pm 0.6 & \pm 0.5 & \pm 0.4 & \pm 0.5 \\
Plasma Free & $\mu$ molL- & $867 \mathrm{a}$ & $914 \mathrm{ab}$ & $827 \mathrm{a}$ & $1179 \mathrm{bc}$ & $1259 \mathrm{c}$ & $932^{\mathrm{ab}}$ & $1090 \mathrm{ab}$ & $902^{\mathrm{a}}$ \\
Amino Acids & 1 & \pm 100 & \pm 66 & \pm 47 & \pm 39 & \pm 147 & \pm 26 & \pm 67 & \pm 44
\end{tabular}

Superscripts denote significant $(\mathrm{P}<0.05)$ differences among dietary treatments within a parameter. Lack of any superscripts within a row indicate that there were no significant differences among any of those treatments for that parameter. 
Fig 1 The relative expression of each gene analysed in this study at both before feeding 0 hrs and 2 hrs post feeding. Before feeding, the Lc G6Pase gene was the most highly expressed of those investigated, along with the Lc GLUD1 gene. Two hours after feeding, relative levels of the $L c G K, L c F A S$ and $L c S C D$ genes had increased above those of $L c$ G6Pase, which had undergone mild repression.

Fig 2 Relative change in gene expression over time after a single feeding event. The expression of many genes was under nutritional regulation, around 2-4 hours after feeding. Expression was significantly elevated in genes that regulate glucose utilisation ( $L c G K, L c P K, L c G 6 P D H, L c P D K$ ), and significantly lower in those that regulate glucose synthesis (Lc G6Pase). Lipid production genes were significantly elevated ( $L c F A S, L c S C D$ and $L c$ acyl), along with those regulating amino acid metabolism ( $L C C A L A T$ ) and energy production ( $L C C S$ ). However, genes that regulate lipid oxidation ( $L C$ CPT1A and Lc PPAR $\alpha$ ) and glycogen breakdown (Lc Pygl) were also active at the same time. Superscripts denote significant $(\mathrm{P}<0.05)$ differences between time points.

Fig 3 Pearson correlation coefficient matrix. The colour of each box shows the relationship between the different parameters analysed in this study, with dark red highlighting positive relationships and dark green highlighting negative relationships. Asterisks denote significant $(\mathrm{P}<0.05)$ correlations between two parameters.

Fig 4 Activation of signalling cascades in response to feeding. A. Specific antibodies were used to quantify levels of phosphorylated (P-Akt; P-mTOR; PS6) relative to non-phosphorylated forms (Akt; mTOR; S6). B. The ratio of the active (phosphorylated) form of each member of the signalling cascade demonstrated that there was a rapid phosphorylation and activation of the mTOR signalling pathway. Superscripts denote significant $(\mathrm{P}<0.05)$ differences between time points. 
Figure 1.

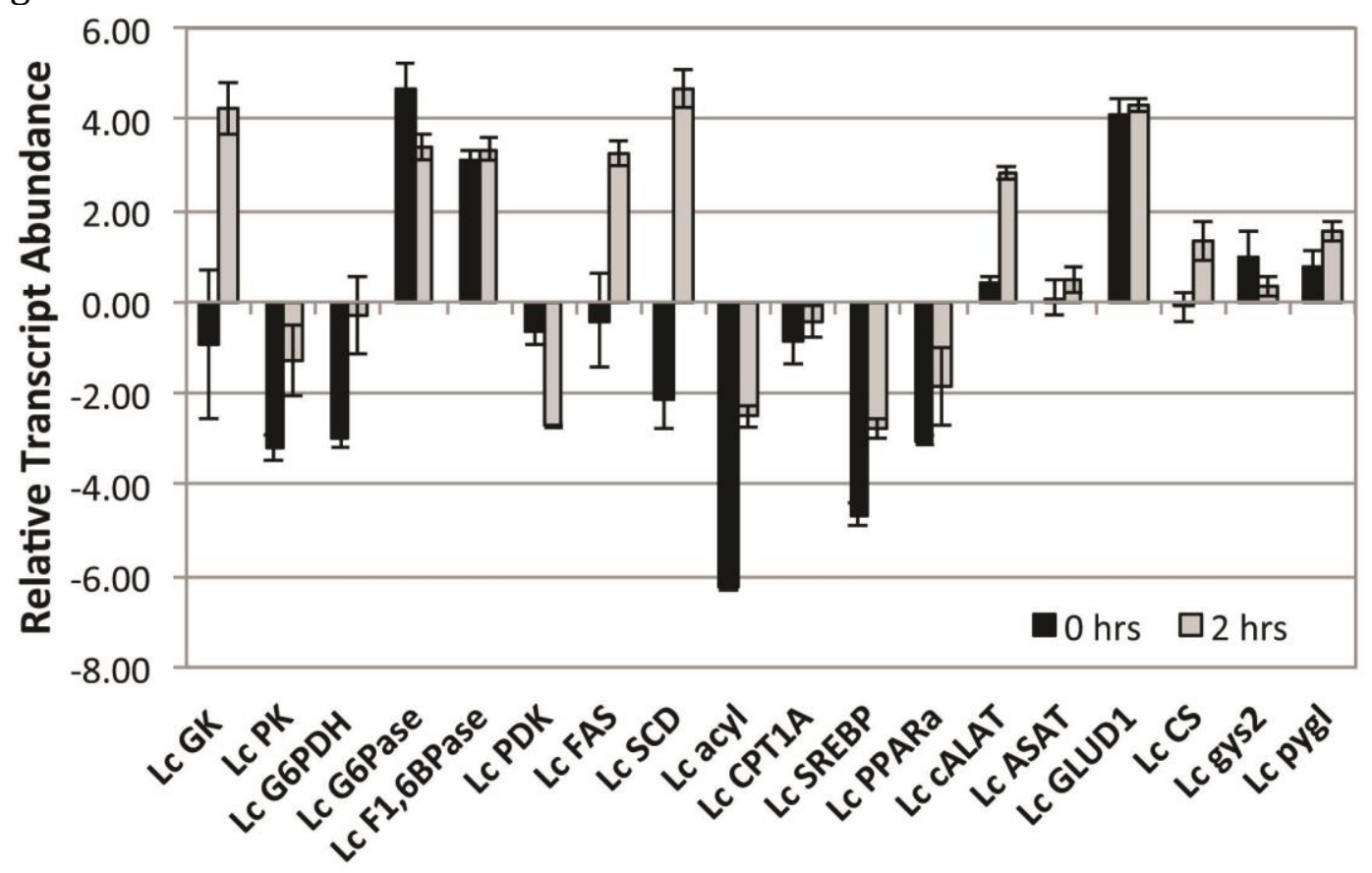


Figure 2. Superscripts denote significant $(\mathrm{P}<0.05)$ differences among time points.

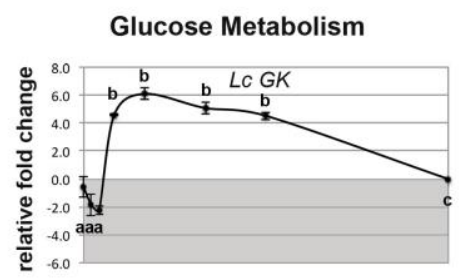

\section{Fatty Acid Metabolism}
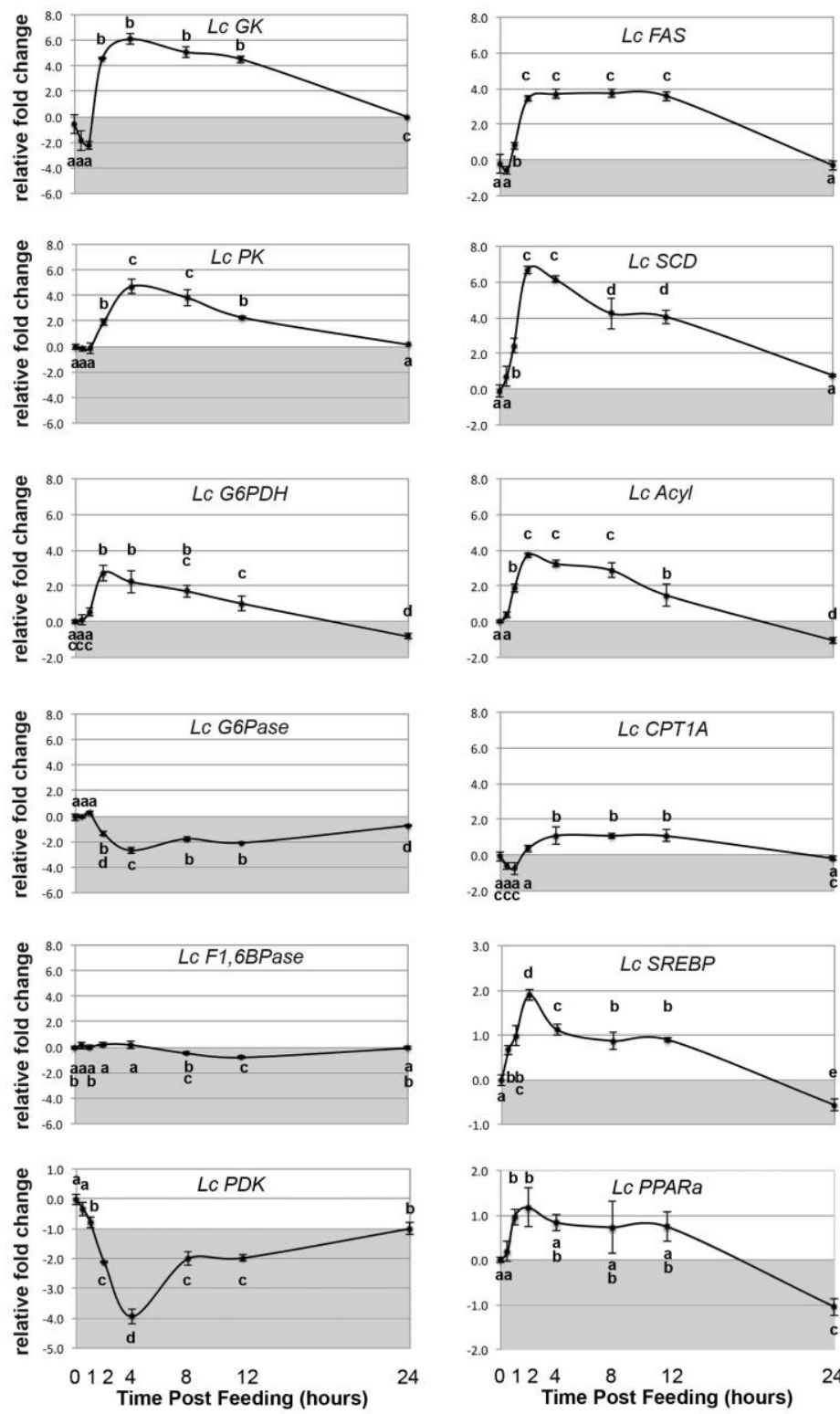
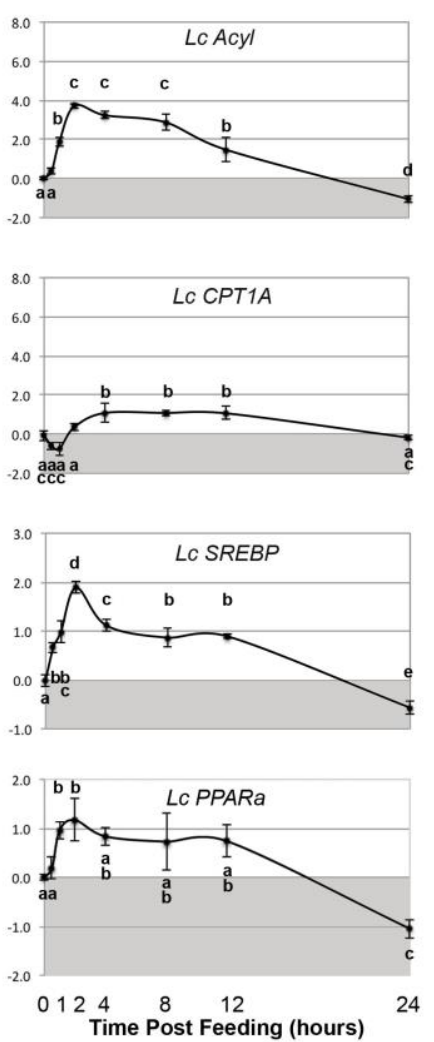

Amino Acid Metabolism
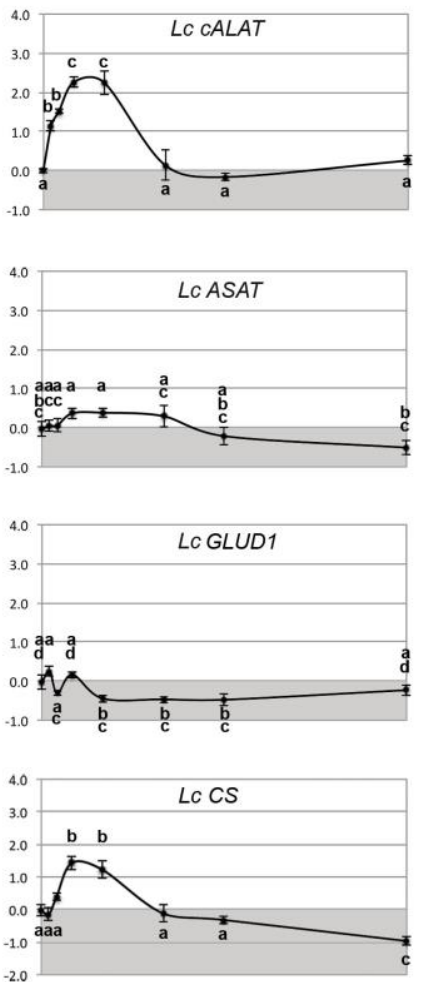

Glycogen Metabolism
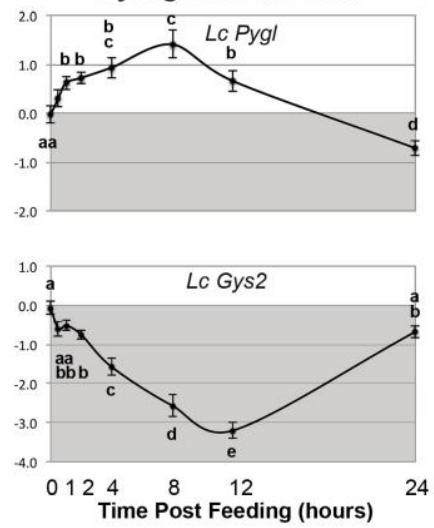
Figure 3. Pearson correlation coefficient matrix.

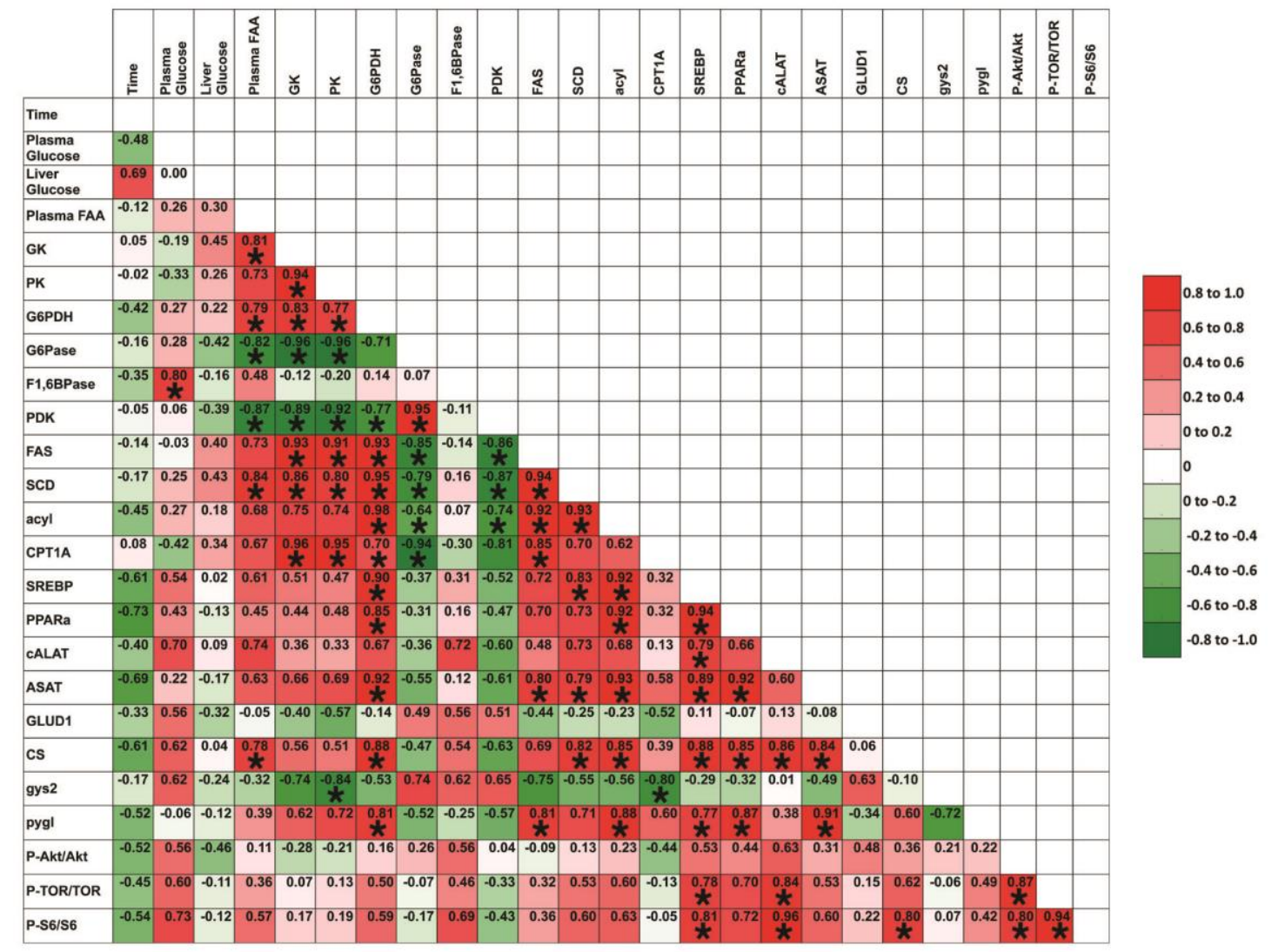


Figure 4. Superscripts denote significant $(\mathrm{P}<0.05)$ differences among time points.

A

\section{$\begin{array}{llllllll}\text { T0 } & \text { T0.5 } & \text { T1 } & \text { T2 } & \text { T4 } & \text { T8 } & \text { T12 } & \text { T24 }\end{array}$}

P-Akt

Akt

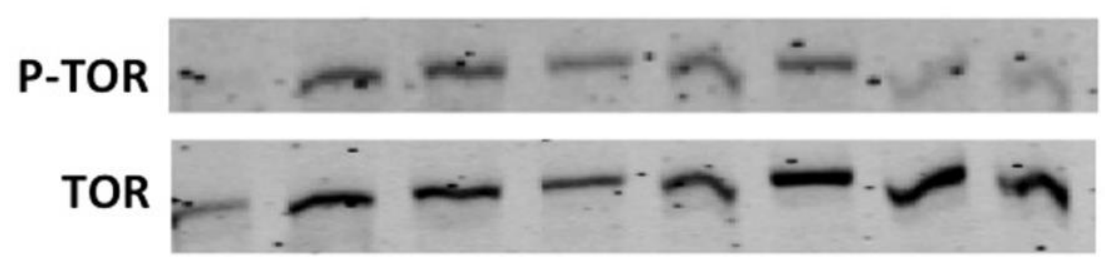

P-S6

S6

B

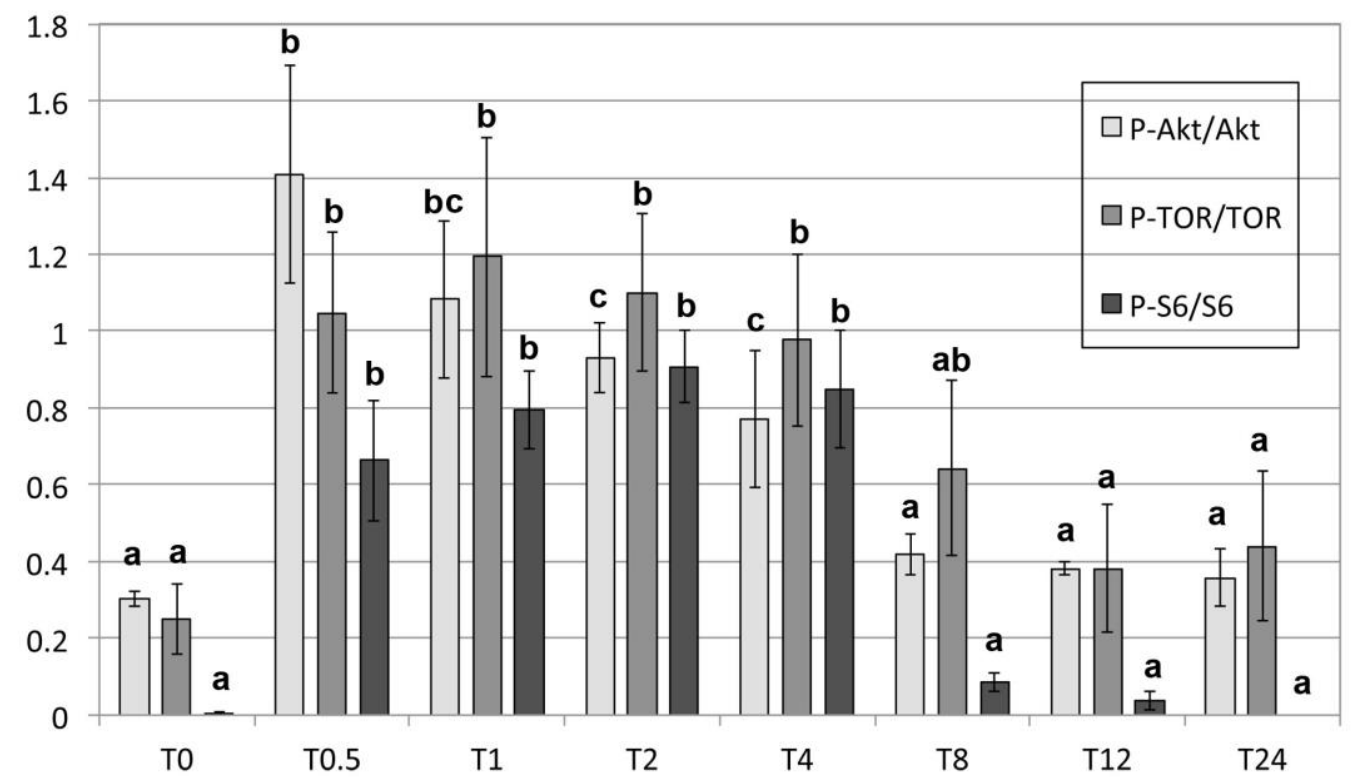

